\title{
Pengaruh Pemahaman Wajib Pajak Tentang PNBP dan Cara Bayar PNBP Terhadap Tingkat Kepatuhan Wajib Bayar pada Perusahaan Tambang (Studi Kasus di Kabupaten Penajam Paser Utara Provinsi Kalimantan Timur)
}

\author{
${ }^{1)}$ Rihfenti Ernayani; ${ }^{2)}$ Butet Wulan Trifina; ${ }^{3)}$ Theresia Wahyuni \\ Fakultas Ekonomi Universitas Balikpapan \\ Jl. Pupuk Raya Balikpapan; Telp./Fax. 0542-764205 \\ E-mail: rihfenti@yahoo.co.id
}

\begin{abstract}
The background of this research is the increase of mining company that has a payment arrears of Non Tax State Revenue to the country. The main problem in this research is the comprehension factor of Non Tax State Revenue and the way to pay Non Tax State Revenue and how it influence to the obedience level of mining company as a payer (case study at district of Penajam Paser Utara). The purpose of this research is to know whether the comprehension of Non Tax State Revenue and how to it influence simultaneous and partially to the obedience level of mining company as a payer. The device that used to collect data that used in this research by used questionnaire. The questionnaires were distributed to 30 companies as IUP holder at district of Penajam Paser Utara. The results of this research shows that comprehension Of Non Tax State Revenue simultaneosly has a significant influence to the obedience level of the payer. Partially, the two variables both the comprehension ofNon Tax State Revenue and the way to pay Non Tax State Revenue has significantly influence to the obedience level of the payer.
\end{abstract}

Keywords: The Comprehension of Non Tax State Revenue, The Way to Pay Non Tax State Revenue, The Obedience of the Payer.

\begin{abstract}
Abstrak
Latar belakang dari penelitian ini adalah semakin maraknya perusahaan tambang yang memiliki tunggakan pembayaran PNBP terhadap Negara. Pokok permasalahan dalam penelitian ini adalah faktor pemahamn PNBP dan cara bayar PNBP berpengaruh terhadap tingkat kepatuhan wajib bayar perusahaan tambang (studi kasus di Kabupaten Penajam Paser Utara). Tujuan penelitian ini adalah untuk mengetahui apakah pemahaman PNBP dan cara bayar PNBP berpengaruh secara parsial dan simultan terhadap tingkat kepatuhan wajib bayar perusahaan tambang. Alat pengumpulan data yang dipakai dalam penelitian ini menggunakan kuesioner. Kuesioner disebar kepada 30 perusahaan pemegang IUP yang berada pada Kabupaten Penajam Paser Utara. Hasil penelitian ini menunjukkan bahwa pemahaman PNBP dan cara bayar PNBP secara simultanmemiliki pengaruh yang signifikan terhadap tingkat kepatuhan wajib bayar. Secara parsial kedua variabel yaitu pemahaman PNBP dan cara bayar PNBP berpengaruh secara signifikan terhadap tingkat kepatuhan wajib bayar.
\end{abstract}

Kata Kunci : Pemahaman PNBP, Cara Bayar PNBP, Kepatuhan Wajib Baya

\section{Pendahuluan}

Undang-undang Nomor 4 tahun 2009 tentang pertambangan mineral dan batubara menjelaskan bahwa pertambangan adalah seluruh tahapan kegiatan dalam rangka penelitian, pengelolaan dan pengusahaan mineral atau batubara yang meliputi penyelidikan Umum, Eksplorasi, Studi Kelayakan, konstruksi, penambangan, pengolahan dan pemurnian, pengangkutan dan penjualan, serta kegiatan pasca tambang, sedangkan usaha pertambangan terdiri atas pertambangan mineral dan pertambangan batubara. Pertambangan mineral sebagai mana dimaksud digolongkan atas pertambangan mineral radioaktif, pertambangan mineral logam, pertambangan mineral bukanlogam, dan pertambangan mineral batuan. Kegiatan 
usaha pertambangan tersebut dilaksanakan Pertambangan), IPR (Izin Pertambangan Rakyat) dan IUPK (Izin Usaha Pertambangan Khusus). Mineral dan Batubara sebagai sumber daya alam yang tak terbarukan merupakan kekayaan nasional yang dikuasai oleh Negara untuk sebesar-besar kesejahteraan rakyat sebagaimana disebutkan dalam Undangundang Nomor 4 tahun 2009 pasal 4. Penguasaan mineral dan batubara oleh Negara diselenggarakan oleh Pemerintah pusat, Provinsi dan Pemerintah Daerah. Adapun kewenangan pemerintah meliputi pembinaan, evaluasi, pengawasan dan pengambilan kebijakan-kebijakan terhadap pemberian IUP.

Fenomena yang terjadi saat ini, banyak perusahaan tambang yang menyalahi aturan yang menyebabkan terjadinya kerugian Negara seperti yang diberitakan oleh Koran Tribun Kaltim hari Jumat tanggal 14 Maret 2014, di Samarinda terdapat 94 IUP batu bara tak bayar pajak. Tak hanya itu data-data mencengangkan terus diungkap dalam Rapat Koordinasi dan Supervisi Pengelolaan Pertambangan Mineral dan Batubara yang digelar Komisi Pemberantasan Korupsi (KPK) di Samarinda, Kamis 13 Maret 2014. Salah satunya soal pengenaan Pajak Bumi Bangunan (PBB). Meski sudah 6.789.819 hektare (ha) luasan areal Izin Usaha Pertambangan (IUP), ternyata baru 364.209 ha yang dikenai kewajiban membayar PBB. Melihat besarnya potensi pendapatan yang masih berstatus piutang, pemerintah pusat member waktu enam bulan kepada semua perusahaan untuk menyelesaikan pembayaran.

Berdasarkan data-data yang diperoleh pada Dinas Pertambangan Kabupaten Penajam Paser Utara terdapat 25 perusahaan pertambangan batubara yang belum melunasi piutang PNBP landrent atau iuran tetap atas temuan Tim BPK-RI tahun 2010.Selain adanya piutang PNBP iuran tetap terdapat pula piutang PNBP royalti atas 3 perusahaan, serta dalam bentuk IUP (Izin Usaha..........)

masih banyak lagi pelanggaranpelanggaran yang dilakukan oleh perusahaan-perusahaan.

Kaltim Post, Jumat tanggal 14 Maret 2014 menyebutkan Tim Komisi Pemberantasan Korupsi pun telah mulai menyelidiki kasus dan kecurangankecurangan yang ada pada kegiatan usaha pertambangan. Terdapat 934 pemegang izin usaha pertambangan yang masih nunggak royalti dan iuran tetap dari aktivitas tambang batubara. Besarnya potensi pendapatan yang masih berstatus piutang, Pemerintah Pusat memberi waktu enam bulan kepada semua perusahaan menyelesaikan pembayaran. Dinas Pertambangan Penajam Paser Utara terbentuk setelah ditetapkannya Peraturan Daerah Kabupaten Penajam Paser utara Nomor 9 tahun 2010 tentang perubahan atas peraturan daerah Kabupaten Penajam Paser Utara Nomor 10 tahun 2008 tentang organisasi dan tata kerja dinas-dinas daerah Kabupaten Penajam Paser Utara, bahwa perangkat daerah Dinas Kehutanan, Perkebunan dan Pertambangan telah dipisah menjadi 2 (dua) dinas yaitu dinas pertambangan dan Dinas Kehutanan dan Perkebunan.

Untuk melaksanakan tugas dan fungsinya, Dinas Pertambangan mengacu pada Undang-undang Nomor 4 tahun 2009 tentang Pertambangan Mineral dan Batubara, yang mana salah satu peraturan dalam undang-undang tersebut menyatakan bahwa Pemegang Izin Usaha Pertambangan (IUP) harus menyelesaikan kewajiban-kewajiban yang telah ditentukan. Salah satu kewajiban pemegang Izin Usaha Pertambangan (IUP) adalah kewajiban finansial. Dalam Peraturan Pemerintah Nomor 23 tahun 2010 tentang Pelaksananaan Kegiatan Usaha Pertambangan Mineral dan Batubara, dijelaskan bahwa salah satu persyaratan finansial IUP Operasi Produksi adalah bukti pembayaran iuran tetap 3 (tiga) tahun terakhir. Seperti yang tercantum dalam Peraturan Pemerintah 
Nomor 29 tahun 2009 tentang tata cara penentuan jumlah, pembayaran dan penyetoran Penerimaan Negara Bukan Pajak yang terhutang bahwa pembayaran Penerimaan Negara Bukan Pajak yang terutang secara tunai paling lambat pada saat jatuh tempo pembayaran sesuai ketentuan peraturan perundang-undangan. Jatuh tempo pembayaran dihitung satu bulan penuh atas terbitnya izin usaha pertambangan.

Kabupaten Penajam Paser Utara sebagai kabupaten baru dapat dikatakan mengalami pertumbuhan dan perkembangan perekonomian yang pesat secara langsung berdampak pada pertumbuhan diberbagai sektor, salah satunya adalah sektor pertambangan. Dengan meningkatnya pengusaha pertambangan baik mineral non logam, batuan dan batubara mempunyai andil dalam penerimaan pendapatan daerah. Pendapatan daerah dari sektor pertambangan yaitu penerimaan negara bukan pajak, yang akan diterima oleh daerah penghasil sebesar $60 \%$ total pendapatan yang ada pada periode 3 bulan sekali setelah dilakukannya rekonsiliasi Penerimaan Negara Bukan Pajak sumber daya alam.

Penerimaan Negara terbagi atas dua jenis, yaitu penerimaan dari pajak dan penerimaan bukan pajak yang disebut Penerimaan Negara Bukan Pajak (PNBP). Menurut Undang-undang Nomor 20 tahun 1997 tentang Penerimaan Negara Bukan Pajak, PNBP adalah seluruh penerimaan Pemerintah Pusat yang tidak berasal dari penerimaan perpajakan. Tanggung jawab atas kewajiban pembayaran PNBP sebagai pencerminan kewajiban pembayaran PNBP berada pada wajib bayar sendiri, apakah wajib bayar telah patuh atau tidak. Wajib bayar diberi kepercayaan untuk menghitung, membayar dan melaporkan sendiri PNBP terutangnya sesuai dengan PP nomor 29 tahun 2009. Dengan menghitung dan membayar sendiri kewajibannya diharapkan kecil terjadi kesalahan oleh Dinas Pertambangan dalam menerapkan sanksi administratif.

Penelitian mengenai tingkat kepatuhan wajib pajak dalam pembayaran pajak sudah banyak, tetapi yang dikaitkan dengan wajib bayar dalam pembayaran Penerimaan Negara Bukan Pajak (PNBP) masih sulit untuk ditemukan Musyarofah dan Purnomo (2008) menyimpulkan bahwa kesadaran wajib pajak dan persepsi tentang sanksi berpengaruh terhadap kepatuhan wajib pajak, sedangkan hasrat membayar pajak tidak berpengaruh terhadap kepatuhan wajib pajak. F. Christanto dan suyanto (2014) menyimpulkan bahwa pemahaman penghindaran pajak mampu menjelaskan tingkat kepatuhan wajib pajak. Wicaksono Murti, J. Sondakh dan Sabijono (2014) wajib pajak dan kualitas pelayanan berpengaruh terhadap kepatuhan wajib pajak.

Melihat telah banyak peneliti yang melakukan penelitian tentang kepatuhan wajib pajak dan melihat kondisi seperti ini dimana aktivitas tambang yang sangat tinggi, kecurangan yang telah dilakukan oleh perusahaan tambang dalam bentuk teknis, lingkungan dan finansial, serta ketidaksesuaian peraturan dengan kondisi riil yang ada, maka yang menjadi permasalahannya adalah; apakah faktor pemahaman wajib pajak tentang PNBP dan pemahaman cara bayar PNBP berpengaruh terhadap tingkat kepatuhan wajib bayar perusahaan tambang? Adapun tujuan penelitian ini untuk mengetahui apakah faktor pemahaman tentang PNBP dan pemahaman cara bayar PNBP berpengaruh terhadap tingkat kepatuhan wajib bayar perusahaan tambang.

\section{Kajian Teoritis Dan Pengembangan Hipotesis \\ 2.1 Pengertian PNBP}

Penerimaan Negara Bukan Pajak (PNBP) merupakan salah satu sumber pendapatan Negara yang pemungutannya dilakukan berdasarkan peraturan perundang- 
undangan di bawah undang-undang, seperti peraturan pemerintah maupun pada departemen atau lembaga non departemen yang bersangkutan. PNBP merupakan pungutan yang dilakukan oleh pemerintah di luar perpajakan atas pelayanan dan pemanfaatan sumber daya alam yang diberikan dan dapat dipaksakan (Djafar Saidi dan Huseng, 2008:15).

\subsection{Tata Cara Pembayaran PNBP}

Berpedoman pada peraturan pemerintah nomor 29 tahun 2009 tentang tata cara penentuan jumlah, pembayaran, dan penyetoran Penerimaan Negara Bukan Pajak yang terutang, Peraturan Pemerintah nomor 09 Tahun 2012 Tentang jenis dan tarif atas jenis Penerimaan Negara Bukan Pajak yang berlaku pada Kementrian Energi dan Sumber Daya Alam, dan Surat Edaran Direktorat Jenderal Mineral dan Batubara nomor 04.E/35/DJB/2012 Tentang penyampaian iuran tetap dan iuran produksi, maka dapat disampaikan beberapa aturan mengenai cara pembayaran PNBP adalah sebagai berikut:

a. Untuk pelaksanaan penyetoran penerimaan negara bukan pajak disebut wajib bayar. Penerimaan negara bukan pajak yang terutang ditentukan dengan cara ditetapkan oleh instansi pemerintah dan dihitung sendiri oleh wajib bayar.

b. Wajib bayar wajib membayar seluruh penerimaan negara bukan pajak yang terutang secara tunai paling lambat pada saat jatuh tempo pembayaran sesuai ketentuan peraturan perundangundangan. Jika wajib bayar melampaui jatuh tempo pembayaran yang ditetapkan,wajib bayar dikenakan sanksi administrasi berupa denda sebesar 2\% (dua persen) per bulan dari bagian yang terutang dan bagian dari bulan dihitung 1 (satu) bulan penuh. Sanksi administrasi berupa denda sebagaimana dimaksud dikenakan untuk paling lama 24 bulan.

c. Jenis penerimaan negara bukan pajak sumber daya alam pertambangan keputusan Menteri yang berlaku

batubara terbagi menjadi dua yaitu iuran tetap (landrent) dan royalti.

d. Setelah perhitungan PNBP dilakukan maka wajib bayar segera membayar PNBP melalui Bank/Pos Persepsi dengan menggunakan Surat Setoran Bukan Pajak (SSBP) untuk pembayaran dalam mata uang rupiah dengan kode akun 421311 (landrent) dan 421312 (royalti).

Dalam penelitian akan dibahas tentang tatacara pembayaran PNBP masih dengan sistem penyetoran menggunakan SSBP/Slip Setor, dikarenakan data dari Dinas Pertambangan sampai dengan saat ini bahwa penyetoran PNBP dengan sistem infornasi PNBP online belum dilakukan oleh perusahaan yang ada di Kabupaten Penajam Paser Utara. Berikut model penelitiannya:

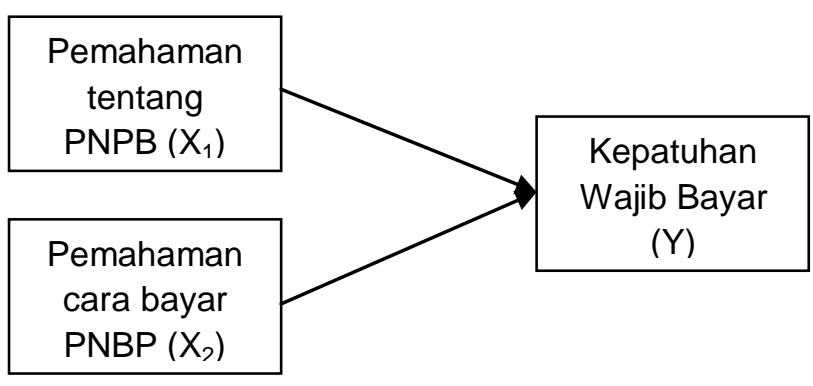

\section{Gambar 1. Model Penelitian}

\subsection{HipotesisPenelitian}

Berdasarkan teori yang digunakan dapat diajukan hipotesis sebagai berikut:

H1. Pemahaman tentang PNBP $\left(\mathrm{X}_{1}\right)$ berpengaruh terhadap tingkat kepatuhan wajib bayar perusahaan tambang (Y).

$\mathrm{H} 2$. Pemahaman cara bayar PNBP $\left(\mathrm{X}_{2}\right)$ berpengaruh terhadap tingkat kepatuhan wajib bayar perusahaan tambang (Y).

H3. Pemahaman tentang PNBP $\left(\mathrm{X}_{1}\right)$ dan pemahaman cara bayar PNBP $\left(\mathrm{X}_{2}\right)$ secara simultan berpengaruh terhadap tingkat kepatuhan wajib bayar perusahaan tambang $(\mathrm{Y})$. 


\section{Metode Penelitian}

\subsection{Definisi Variabel Penelitian}

Variabel yang digunakan dalam penelitian ini adalah pemahaman tentang PNBP dan pemahaman cara bayar PNBP sebagai variabel independen, sedangkan tingkat kepatuhan wajib bayar sebagai variabel dependen.

1. Pemahaman Tentang PNBP $\left(\mathrm{X}_{1}\right)$ adalah suatu sikap yang menjelaskan bahwa seorang atau sebuah badan usaha memiliki pengetahuan dan pemahaman atas PNBP yang merupakan salah satu kewajibannya dalam kegiatan usaha pertambangan. Instrumen yang digunakan untuk mengukur variabel ini terdiri dari 5 item pertanyaan dengan pengukuran skala likert's.

2. Pemahaman Cara Bayar Pajak $\left(X_{2}\right)$ adalah suatu sikap yang menjelaskan bahwa seorang atau sebuah badan usaha wajib mengetahui tata cara pembayaran PNBP, yang merupakan salah satu sistem Self Assesment yaitu menghitung, membayar dan melaporkan kepada pihak terkait. Instrumen yang digunakan untuk mengukur variabel ini terdiri dari 5 item pertanyaan dengan pengukuran skala likert's.

3. Tingkat Kepatuhan Wajib Bayar $\left(\mathrm{Y}_{1}\right)$ adalah suatu sikap yang menjelaskan bahwa wajib bayar telah melaksanakan kewajibannya sesuai dengan ketentuan Undang-undang yang berlaku. Instrumen yang digunakan untuk mengukur variabel ini terdiri dari 5 item pertanyaan dengan pengukuran skala likert's.

\subsection{Metode Pengumpulan data}

Metode penelitian yang digunakan adalah metode deskriptif analisis dengan cara menggunakan kuesioner yang disebar secara langsung kepada responden. Secara spesifik responden yang dipilih adalah direktur perusahaan selaku pemegang IUP yang bertanggung jawab penuh atas kewajiban pembayaran berdasarkan pada lampiran kewajiban IUP yang diterbitkan oleh Bupati. Kuesioner berisi sejumlah pertanyaan yang harus dijawab sesuai dengan pendapat mereka masing-masing.

\subsection{Populasi dan Sampel}

Populasi yang dipilih dalam penelitian ini adalah seluruh perusahaan tambang batubara Izin Usaha Pertambangan Operasi Produksi (IUP-OP) di Kabupaten Penajam Paser Utara. Jumlah IUP pertambangan batubara yang berada di Kabupaten Penajam Paser Utara terdiri dari 45 IUP Operasi Produksi. Untuk menetapkan jumlah sampel dilakukan dengan menggunakan cara proportionate stratified random sampling dengan cara membagi populasi menjadi 2 strata, perusahaan yang telah melakukan penjualan dan perusahaan yang belum melakukan penjualan. Langkah berikutnya, menentukan jumlah sampel minimal masing-masing strata dengan membagi jumlah sampel secara proporsional. Sampel dapat ditentukan oleh peneliti sesuai dengan teori yang telah peneliti pilih. Untuk memudahkan penentuan sampel maka membagi data berdasarkan kriteria kegiatan pemegang izin usaha pertambangan operasi produksi yaitu kegiatan yang telah melakukan penjualan dan kegiatan yang belum melakukan penjualan. Berdasarkan hal tersebut diperoleh sampel sebanyak 30 .

\subsection{Teknik Analisis Data}

Dalam proses pengumpulan data, instrumen atau alat yang dipakai adalah kuesioner yang berisi pertanyaanpertanyaan yang harus dijawab oleh responden. Kuesioner dinilai dengan skala Likert 5 Point.

Pengujian hipotesis penelitian menggunakan metode analis regresi linier berganda dengan bantuan program SPSS 20.0 for windows, sedangkan teknik analisis yang digunakan meliputi: (1) Validitas dan Reliablitas, (2) uji asumsi klasik yaitu untuk menguji kelayakan penggunaan model regresi (Ghozali, 2007). Uji asumsi klasik terdiri dari uji 
multi kolinearitas, uji heteroskedastitas dan uji auto korelasi. (3) metode regresi berganda yang meliputi uji $\mathrm{t}$ (parsial) danuji F (simultan).

\section{Hasil Dan Pembahasan}

\subsection{Gambaran Responden}

Karakteristik responden sebanyak 30 berdasarkan masa berlaku IUP secara presentase sebagai berikut, masa berlaku IUP dua tahun sebanyak 1 responden atau pemegang IUP dengan presentase 3,33\%, masa berlaku IUP tiga tahun sebanyak 4 responden atau pemegang IUP dengan presentase $13,33 \%$, masa berlaku IUP empat tahun sebanyak 1 responden atau pemegang IUP dengan presentase 3,33 \%, masa berlaku IUP lima tahun sebanyak 22 responden atau pemegang IUP dengan presentase $73,33 \%$, masa berlaku IUP enam tahun sebanyak 2 responden atau pemegang IUP dengan presentase 13,33 $\%$.

Berdasarkan pengumpulan data diperoleh klasifikasi tahapan kegiatan pemegang izin usaha pertambangan yang digunakan sebagai sampel dalam penelitian ini. Secara rinci tahapan kegiatan diuraikan sebagai berikut: untuk tahapan kegiatan produksi dan penjualan sejumlah 14 pemegang IUP dengan presentasi 46,67 \%, tahap kegiatan produksi sejumlah 4 pemegang IUP dengan presentase $13,33 \%$, kemudian untuk pemegang IUP yang belum melakukan kegiatan sejumlah 12 pemegang IUP dengan presentase $40 \%$.

\subsection{Pengujian Instrumen}

\subsubsection{Validitas}

Penelitian ini setiap instrumen pertanyaan menunjukkan valid, dimana masing-masing pertanyaan telah diuji melalui metode statistik yang menyatakan bahwa hasil dari $r$ hitung $>r$ tabel.

\subsubsection{Uji Reliabilitas}

Berdasarkanhasildiketahui bahwa variabel dalam penelitian ini memiliki nilai pada cronbach's Alpha 0,8, yang berarti lebih besar dari 0,6, maka dapat disimpulkan bahwa alat ukur di dalam penelitian ini adalah reliabel.

\subsection{Analisis}

\subsubsection{Uji Asumsi Klasik}

Uji asumsi klasik yang dilaksanakan pada penelitian ini yaitu uji normalitas data, uji multi kolinearitas dan uji heteroskedastisitas. Berdasarkan hasil analisis maka didapatkan kesimpulan bahwa regeresi linier berganda layak untuk digunakan.

\subsubsection{Analisis Regresi Linear Berganda}

Analisis regresi linier berganda digunakan untuk mengetahui pengaruh antara dua atau lebih variabel independen dengan satu variabel dependen. Persamaan regresi ini memuat nilai konstanta atau intercept nilai koefisien regresi yang terbentuk. Dari hasil pengujian regresi linier berganda dalam penelitian ini ditampilkan pada tabel berikut :

Tabel 1. Hasil Uji Regresi Linier

\begin{tabular}{|l|r|r|r|r|r|}
\hline Model & \multicolumn{2}{|c|}{$\begin{array}{c}\text { Unstandardized } \\
\text { Coefficients }\end{array}$} & $\begin{array}{c}\text { Stand } \\
\text { ardize } \\
\mathrm{d} \\
\text { Coeffi } \\
\text { cients }\end{array}$ & $\mathrm{t}$ & Sig. \\
\cline { 2 - 5 } & $\mathrm{B}$ & $\begin{array}{c}\text { Std. } \\
\text { Error }\end{array}$ & Beta & & \\
\hline $\begin{array}{l}\text { (Constant) } \\
\begin{array}{l}\text { Pemahaman } \\
\text { PNBP }\end{array}\end{array}$ & 2,469 & 1,160 & & 2,129 &, 043 \\
$\begin{array}{l}\text { Pemahaman } \\
\text { Cara Bayar } \\
\text { PNBP }\end{array}$ &, 629 &, 081 &, 689 & 7,772 &, 000 \\
\hline
\end{tabular}

Sumber : Data Primer Yang Telah

Diolah

Dari tabel di atas, didapat persamaan regresi linier berganda sebagai berikut :

$$
\mathrm{Y}=\mathbf{2 , 4 6 9}+\mathbf{0 , 3 1 4} \mathrm{X} 1+0,629 \times 2+\mathrm{e}
$$

\subsubsection{Uji Goodnes Of Fit \\ Hasil Uji F}

Tabel 2. Hasil Uji F

\begin{tabular}{|l|c|c|c|c|c|}
\hline Model & $\begin{array}{c}\text { Sum of } \\
\text { Squares }\end{array}$ & Df & $\begin{array}{c}\text { Mean } \\
\text { Square }\end{array}$ & F & Sig. \\
\hline
\end{tabular}




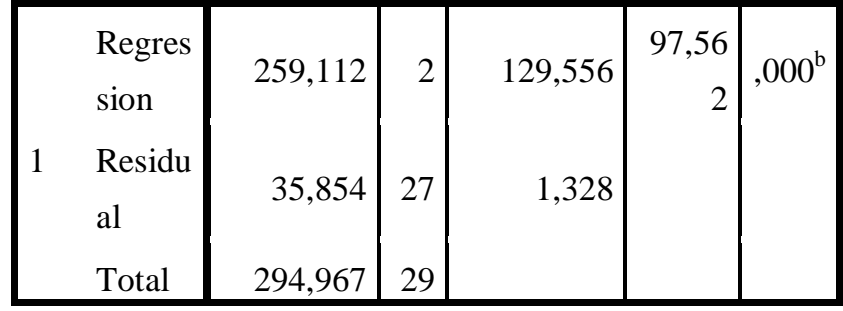

Sumber : Data Primer Yang Telah Diolah

Dari hasil uji statistik $F$ menunjukkan bahwa nilai $\mathrm{F}$ hitung $>\mathrm{F}$ tabel yaitu dengan nilai 97,562>3,340 dan dengan tingkat signifikan nilai probabilitas $<0,05$ atau 0,000 $<0,05$. Hasil dari perhitungan tersebut maka hipotesis dapat diterima, sehingga dapat dikatakan bahwa pemahaman PNBP dan pemahaman cara bayar PNBP berpengaruh secara simultan terhadap tingkat kepatuhan wajib bayar.

\section{Hasil Uji Parsial (uji t)}

Berdasarkan tabel HasilUji Linier pengujian statistik t dapat disimpulkan; untuk variabel pemahaman PNBP mempunyai tingkat signifikasi 0,001 dan memiliki nilai $\mathrm{t}$ hitung sebesar 3,698. Dapat disimpulkan bahwa hipotesis pertama diterima sehingga dapat dikatakan bahwa pemahaman PNBP berpengaruh positif dan signifikan terhadap kepatuhan wajib bayar karena tingkat signifikan yang dimiliki oleh variabel pemahaman PNBP adalah $0,001<0,05$ dan nilai t 3,698 > 1,701. Untuk pengujian hipotesis kedua hipotesis kedua diketahui bahwa variabel Pemahaman cara bayar PNBP berpengaruh positif dan signifikan terhadap kepatuhan wajib bayar karena memiliki tingkat signifikan yang dimiliki oleh variabel pemahaman cara bayar PNBP adalah $0,000<0,05$ dan nilai $\mathrm{t} 7,772>1,701$.

\section{Hasil uji Koefisien Determinasi $\left(\mathbf{R}^{2}\right)$}

Adjusted R Square merupakan koefisien determinasi yang telah dikoreksi dengan jumlah variabel dan ukuran sampel sehingga dapat mengurangi unsur bias jika terjadi penambahan variabel maupun penambahan ukuran sampel. Hasil Koefisien adjusted $\mathrm{R}$ square sebesar 0,869 diperoleh dari uji statistik sebagai berikut:
Tabel3.HasilUjiKoefisienDeterminasi

\begin{tabular}{|c|c|c|c|c|c|}
\hline $\begin{array}{l}\text { Mod } \\
\text { el }\end{array}$ & $\mathrm{R}$ & $\begin{array}{c}\mathrm{R} \\
\text { Squar } \\
\mathrm{e}\end{array}$ & $\begin{array}{c}\text { Adjuste } \\
\text { d R } \\
\text { Square }\end{array}$ & $\begin{array}{l}\text { Std. } \\
\text { Error } \\
\text { of the } \\
\text { Estima } \\
\text { te }\end{array}$ & $\begin{array}{c}\text { Durbin } \\
- \\
\text { Watso } \\
\mathrm{n}\end{array}$ \\
\hline 1 &, $937^{\mathrm{a}}$ & 878 & 869 & 1,152 & 1,736 \\
\hline
\end{tabular}

Diolah

Dari tabel diatas diketahui bahwa Adjusted R Square sebesar 0,869 berarti variasi kepatuhan wajib bayar dapat dijelaskan oleh variasi pemahaman PNBP dan pemahaman cara bayar PNBP sebesar 86,9 persen atau pemahaman PNBP dan pemahaman cara bayar PNBP mempengaruhi variabel kepatuhan wajib bayar sebesar 86,9 persen.

\subsection{Pembahasan Pemahaman tentang} PNBP $\left(X_{1}\right)$ terhadap Tingkat Kepatuhan Wajib Bayar Perusahaan Tambang (Y)

Hasil pengujian hipotesis bahwa variabel pemahaman PNBP memiliki pengaruh yang signifikan terhadap tingkat kepatuhan wajib bayar. Hal ini terlihat dari nilai $\mathrm{t}$ hitung adalah lebih besar dari nilai $\mathrm{t}$ tabel atau 3,698>1,701 dengan nilai probabilitas sig. $0,001<0,05$.

Dalam penelitian ini wajib bayar menilai bahwa pemahaman PNBP sangat berpengaruh terhadap tingkat kepatuhan wajib bayar. Semakin tidak paham wajib bayar terhadap pengertian dari penerimaan Negara bukan pajak maka semakin tinggi juga niat para wajib bayar untuk tidak membayar PNBP. Hal ini dikarenakan bahwa sebagian besar dari pemegang izin usaha pertambangan hanya berorientasi untuk menghasilkan keuntungan dari perut bumi yaitu sumber daya alam berupa batubara dan tidak memperdulikan kewajiban yang terikat dan tercantum pada surat keputusan izin usaha pertambangan yang dimiliki. Maka dengan keadaan seperti ini yang membuat resah dan 
menghilangkan kemauan wajib bayar untuk melaksanakan kewajibannya sebagai warga negara yang baik yaitu dengan membayar kewajibannya yang sesuai dengan peraturan dan undang-undang yang berlaku.Setiap perusahaan memang harus mengerti dan memahami tentang pengertian PNBP itu sendiri, dikarenakan bahwa perusahaan memegang peranan penting dalam pembayaran PNBP, seperti yang tercantum dalam Peraturan Pemerintah Nomor 29 tahun 2009. Kondisi ini menunjukkan pula pemahaman PNBP merupakan hal penting yang perlu disadari oleh masing-masing perusahaan untuk dapat memahami secara langsung pengertian dari PNBP tersebut. Pemahaman PNBP yang baik akan menghasilkan kepatuhan wajib bayar yang baik dan pada akhirnya akan tercipta serta terwujud kesejahteraan sosial dan kemakmuran rakyat.

Pemahaman Cara Bayar PNBP $\left(\mathbf{X}_{2}\right.$ terhadap Tingkat Kepatuhan Wajib Bayar Perusahaan Tambang (Y)

Bukti empiris dari hasil penelitian ini menunjukkan bahwa $\mathrm{t}$ hitung sebesar 7,772 > 1,701, hasil ini menunjukkan bahwa pemahaman cara bayar PNBP berpengaruh secara parsial terhadap kepatuhan wajib bayar dan berpengaruh secara signifikan dengan nilai sig $<0,05$ yaitu $0,000<0,05$. Pengujian hipotesis ke dua menunjukkan adanya pengaruh signifikan dari variabel pemahaman cara bayar PNBP terhadap variabel kepatuhan wajib bayar.

Hasil ini menujukkan pemahaman cara bayar PNBP merupakan pengaruh bagi wajib bayar dalam pembayaraan PNBP. Perilaku wajib bayar dengan tidak memahami cara bayar PNBP merupakan wujud kelalaian bagi pihak perusahaan untuk tidak melaksanakan dan tidak mengetahui tata cara dalam mengambil keuntungan finansial dari sumber daya alam (batubara). Dari analisis dan fakta yang ada bahwa pemahaman tatacara pembayaran PNBP ini berpengaruh terhadap kepatuhan wajib bayar yang dapat merugikan Negara. Hal ini berpengaruh pada pertumbuhan ekonomi, kemakmuran rakyat serta pembangunan infrastruktur, selain daripada hal tersebut faktor dari alampun mendapat kerugian yang cukup dalam hal pertambangan yang tidak sesuai dengan ketentuan.

\section{Pemahaman PNBP $\left(X_{1}\right)$ dan Cara} Bayar PNBP $\left(X_{2}\right)$ terhadap Tingkat Kepatuhan Wajib Bayar Perusahaan Tambang (Y)

Dari hasil uji F dapat diketahui bahwa variabel independen yaitu pemahaman PNBP dan cara bayar PNBP berpengaruh secara simultan terhadap variabel dependen yaitu kepatuhan wajib bayar. Bukti empiris menunjukkan bahwa nilai $F$ hitung lebih besar dari nilai $F$ tabel dan dengan tingkat signifikan lebih kecil dari 0,05. Nilai $F$ hitung yaitu 97,562 > 3,340 dengan nilai sig $0,000<0,05$.

Sikap pemahaman PNBP serta pemahaman cara bayar PNBP harus segera ditingkatkan, jika tindakan ini dilakukan terus menerus maka tidak hanya pembangunan Negara yang terhambat namun kesejahteraan masyarakat kecil pun akan ikut terhambat dan merasakan pengaruh dari ketidakpatuhan wajib bayar.Dengan kondisi yang ada dilapangan dimana kepatuhan wajib bayar selama ini masih terbilang kurang. Hal ini ditunjukkan data pada dinas pertambangan Kabupaten Penajam Paser Utara dengan adanya temuan atas pemeriksaan badan pemeriksa keuangan tahun anggaran 2010. Kondisi seperti ini harus ada perubahan dan kemajuan dalam hal pemahaman Penerimaan Negara Bukan Pajak serta cara bayar penerimaan Negara bukan pajak sesuai dengan peraturan yang berlaku.

\section{Penutup}

Berdasarkan hasil penelitian dan analisis yang dilakukan pada perusahaan tambang yang berada pada Kabupaten Penajam Paser Utara untuk mengetahui adanya pengaruh pemahaman PNBP dan cara bayar PNBP terhadap tingkat 
kepatuhan wajib bayar, maka dapat menarik kesimpulan ebagai berikut:

1. Pemahaman PNBP berpengaruh positif signifikan terhadap kepatuhan wajib bayar perusahaan tambang, dimana hasil $t$ hitung menunjukkan nilai yang lebih besar daripada nilai $t$ tabel. Dengan merujuk pada teori yang ada bahwa suatu variabel dapat dikatakan berpengaruh secara parsial jika variabel tersebut telah melalui analisis data dengan ketentuan serta kriteria ditentukan.

2. Pemahaman cara bayar PNBP berpengaruh positif signifikan terhadap kepatuhan wajib bayarperusahaan tambang, hal ini ditunjukkan dalam hasil analisis uji statitik $\mathrm{t}$ bahwa $\mathrm{t}$ hitung menunjukkan angka lebih kecil dari t tabel.

3. Pemahaman PNBP dan cara bayar PNBP secara simultan berpengaruh positif signifikan terhadap tingkat kepatuhan wajib bayar perusahaan tambang. Dari hasil analisis yang ada diketahui bahwa uji statistik $\mathrm{F}$ menunjukkan nilai $\mathrm{F}$ hitung lebih besar dari nilai $\mathrm{F}$ tabel.

\section{Daftar Pustaka}

Djafar Saidi, Muhammad dan Huseng, Rohana. (2008). Hukum Penerimaan Negara Bukan Pajak. Jakarta. Kharisma Putra Utama Offset.

Edaran Nomor 04.E/ 35/ DJB/ 2012. 2012. tentang Penyampaian Iuran Tetap dan Iuran Produksi. Jakarta.

Edaran Nomor 07.E/35/DJB/2014. 2014. tentang Tata cara Pembayaran/ Penyetoran Penerimaan Negara Bukan Pajak dan Penerimaan Non Anggaran Secara Elektronik dari Sumber Daya Alam Mineral dan Batubara. Jakarta.

F. Christianto, Valentinus dan Suyanto. 2014. Pengaruh Pemahaman Tindak Pidana Korupsi dan Pemahaman
Penghindaran Pajak Terhadap Tingkat Kepatuhan Wajib Pajak dalam Pembayaran Pajak di Daerah Istimewa Yogyakarta. Jurnal Akuntansi Fakultas Ekonomi Universitas Sarjanawiyata Tamansiswa, ISSN 1412-5366.

Musyarofah, Siti dan Purnomo, Adi. Pengaruh Kesadaran dan Persepsi Tentang Sanksi, dan Hasrat Membayar Pajak terhadap Kepatuhan Wajib Pajak. Jurnal Akuntansi, Manajemen Bisnis Vol. 5 No. 1 ISSN 1829-9857.

Peraturan Daerah Kabupaten Penajam Paser Utara No 09. 2010. Tentang perubahan atas peraturan daerah Kabupaten Penajam Paser Utara Nomor 10 tahun 2008 tentang organisasi dan tata kerja dinas-dinas daerah Kabupaten Penajam Paser Utara

Peraturan Pemerintah Republik Indonesia No 23. 2010. Pelaksananaan Kegiatan Usaha Pertambangan Mineral dan Batubara

Peraturan Pemerintah Republik Indonesia No 29. 2009. tentang Tata cara tentang Penentuan Jumlah, Pembayaran dan Penyetoran Penerimaan Negara Bukan Pajak yang Terutang

Peraturan Pemerintah Republik Indonesia No 09. 2012. tentang Jenis dan Tarif atas Jenis Penerimaan Negara Bukan Pajak yang Berlaku pada Kementrian Energi dan Sumber Daya Mineral. Jakarta.

Sugiyono. 2013. Metode Penelitian Kuantitatif Kualitatif dan $R \quad \& \quad D$. Bandung. Penerbit Alfabeta.

Sumarsono, Sonny. 2010. Manajemen Keuangan Pemerintahan. Yogyakarta. Graha Ilmu.

Undang-undang Republik Indonesia No 20. 1997. Tentang Penerimaan Negara Bukan Pajak 
Undang-undang Republik Indonesia No 04. 2009. Tentang Pertambangan Mineral dan Batubara

Wicaksono Murti, Hangga. J. Sondakh, Jullie dan Sabijono, Harijanto. 2014. Pelayanan Fiskus dan Pengetahuan Perpajakan terhadap Kepatuhan Wajib Pajak Orang Pribadi di Kota Manad. Jurnal EMBA, Vol.2 No.3 ISSN 23031174. 